\section{OPEN ACCESS}

Edited by:

Arkadiusz Miazek,

Polish Academy of Sciences, Poland

Reviewed by:

Jens Staal,

Ghent University, Belgium

Ernesto Diaz-Flores,

University of California, United States

*Correspondence:

Flavia Castellano

flavia.castellano@inserm.fr

Valérie Molinier-Frenkel

valerie.frenkel@inserm.fr

Specialty section:

This article was submitted to

Signaling,

a section of the journa

Frontiers in Cell and Developmental

Biology

Received: 02 October 2020

Accepted: 30 November 2020

Published: 17 December 2020

Citation:

Castellano F and

Molinier-Frenkel V (2020) Control of T-Cell Activation and Signaling by

Amino-Acid Catabolizing Enzymes.

Front. Cell Dev. Biol. 8:613416.

doi: 10.3389/fcell.2020.613416

\title{
Control of T-Cell Activation and Signaling by Amino-Acid Catabolizing Enzymes
}

\author{
Flavia Castellano ${ }^{1,2 *}$ and Valérie Molinier-Frenkel ${ }^{1,2 *}$ \\ ${ }^{1}$ Univ Paris Est Creteil, INSERM, IMRB, Creteil, France, ${ }^{2}$ AP-HP, Hopital Henri Mondor, Departement \\ Immunologie-Hématologie, Creteil, France
}

Amino acids are essential for protein synthesis, epigenetic modification through the methylation of histones, and the maintenance of a controlled balance of oxidoreduction via the production of glutathione and are precursors of certain neurotransmitters. T lymphocytes are particularly sensitive to fluctuations in amino acid levels. During evolution, the production of amino-acid catabolizing enzymes by mainly antigenpresenting cells has become a physiological mechanism to control T-cell activation and polarization. The action of these enzymes interferes with TCR and co-stimulation signaling, allowing tuning of the T-cell response. These capacities can be altered in certain pathological conditions, with relevant consequences for the development of disease. Keywords: amino acids, amino acid transporters, amino acid catabolizing enzymes, TCR signaling,
immunoregulation

\section{INTRODUCTION}

The activation of antigen-specific $\mathrm{T}$ lymphocytes drives them from quiescence to rapid clonal expansion, accompanied by effector differentiation. These profound functional modifications are permitted by rapid changes in metabolic programming to fulfill the abrupt increase in the requirement of nutrients and energy. Thus, lymphocytes are particularly vulnerable to alterations of the metabolic microenvironment.

Various amino-acid catabolizing enzymes expressed by stromal and immune cells have been identified and shown to be important regulators of these processes by reducing the level of essential amino acids available to proliferating $\mathrm{T}$ cells and, in certain cases, by producing bioactive compounds that affect cell viability and/or proliferation. As a consequence, these enzymes contribute to the immunosuppressive state involved in the development of cancer, and defective induction of their expression is suspected to conversely trigger autoimmunity.

In this review, we discuss aspects related to the modification of TCR signaling and their consequences on T-cell activation, proliferation, and differentiation resulting from variations in the level of amino acids and the presence of catabolites of amino-acid catabolizing enzymes. 


\section{AMINO-ACID TRANSPORT}

The substantial new requirements of activated lymphocytes are fulfilled by activation-induced mechanisms. In particular, their highly rapid duplication requires amino acids for protein synthesis. Naive human primary $\mathrm{T}$ cells express an almost undetectable amount of amino-acid transporters (Ren et al., 2017). Some of the major transporters belong to the SLC7 family, which is comprised of cationic amino-acid transporters (CATs) and the light subunits of large amino-acid transporters (LATs). CATs are $\mathrm{N}$-glycosylated membrane proteins specialized in the transport of cationic amino acids, e.g., arginine, lysine, and histidine. The heterodimeric LATs show broader substrate specificity toward different types of amino acids (neutral, cationic, negatively charged, etc.). SLC7A5, also known as LAT1, interacts with the glycoprotein SLC3A2 (CD98) to form a heterodimeric transporter dedicated to essential amino acids (tryptophan, phenylalanine and leucine, and to a lesser extent, histidine and glutamine). LAT1 can also transport several aromatic amino acid-related compounds, such as L-DOPA (Uchino et al., 2002) and citrulline, an intermediate catabolite from which arginine can be synthesized (Werner et al., 2017).

Both types of transporters are expressed within $24 \mathrm{~h}$ of T-cell activation (Hayashi et al., 2013; Sinclair et al., 2013). The induction of LAT1 in primary human T cells stimulated in vitro is dependent on activator protein-1 (AP-1) and nuclear factor- $\kappa \mathrm{B}$ $(\mathrm{NF}-\kappa \mathrm{B})$ signaling. When LAT1 expression is blocked, cytokine secretion by T cells is impaired, suggesting that LAT1 is required for their full activation (Hayashi et al., 2013). Silencing of human CAT-1 in primary $\mathrm{T}$ lymphocytes for $24 \mathrm{~h}$ reduces arginine transport by $64 \%$ relative to control cells, resulting in a significant reduction of proliferation, whereas IFN $\gamma$, IL-2, and IL-6 secretion are not affected (Werner et al., 2016).

Thus, $\mathrm{T}$ cells can modulate the uptake of amino acids, in particular essential amino acids, to accommodate changes in their microenvironment and metabolic requirements (Figure 1).

\section{AMINO-ACID CATABOLIZING ENZYMES}

Amino-acid degrading enzymes have been shown over the last 20 years to be central players in the control of T-cell proliferation and differentiation. This category of molecules is mostly produced by antigen-presenting cells (APC). APCs use amino-acid catabolizing enzymes to reduce the availability of essential and semi-essential amino acids for T-cell activation in negative feedback control mechanisms of the immune response. Indeed, during T cell-APC cross-talk, APC activation leads to slightly delayed induction of the synthesis of some of these enzymes (Braun et al., 2005; Marquet et al., 2010).

Although genetically unrelated in most cases, these enzymes all act by degrading an amino acid and, in some cases, producing bioactive catabolites (Table 1). They can be classified based on their amino-acid substrate. Indoleamine 2,3, dioxygenase (IDO)1, its isoform IDO2, and tryptophan 2,3-dioxygenase (TDO) degrade tryptophan, whereas the arginases (Arg), Arg1 and Arg2, and the nitric oxide synthases (NOS), including inducible NOS (iNOS) and endothelial NOS (eNOS), degrade arginine (neuronal NOS is not expressed in the immune system). Finally, Interleukin 4 induced gene 1 (IL4I1) mainly degrades phenylalanine. IL4I1 is also able to catabolize tryptophan and arginine, although its activity against these amino acids is much lower (at least five-fold) than that toward phenylalanine [(Boulland et al., 2007; Yue et al., 2015; Molinier-Frenkel et al., 2016) and personal data].

These enzymes can also be divided between those that limit availability of their substrate amino acid (IDO1, IDO2, TDO, Arg1, Arg2, and IL4I1) and those that liberate products that are inhibitory or proapoptotic for T cells. The IDOs and TDO produce kynurenines (Kyns), iNOS and eNOS produce nitric oxide (NO), and IL4I1 liberates two toxic compounds, hydrogen peroxide $\left(\mathrm{H}_{2} \mathrm{O}_{2}\right)$ and ammonia $\left(\mathrm{NH}_{3}\right)$, while converting its amino acid substrate into its ketoacid form. In a recent study, IL4I1 activity toward tryptophan was shown to produce the ketoacid indole-3-pyruvate, which may function as a precursor that can enter the Kyn pathway (Sadik et al., 2020). The enzymatic activity of iNOS can change when co-expressed with arginase. Under such conditions, the consumption of arginine by Arg1 favors the production of superoxide by iNOS. The interaction of $\mathrm{NO}$ with anion superoxide $\left(\mathrm{O}_{2}{ }^{-}\right)$leads to the production of peroxynitrite, an extremely reactive compound (Xia and Zweier, 1997).

In the immune system, cells of myeloid origin are the main producers of these enzymes, with certain species-related differences. The main example is Arg1, which is constitutively expressed by granulocytes in humans, whereas it is a hallmark of macrophages activated by Th2 cytokines (M2) in mice (Munder et al., 1999). Mitochondrial Arg2, iNOS and eNOS can also be expressed by T cells (Ibiza et al., 2006; Yang et al., 2013; Geiger et al., 2016). iNOS is also expressed by mouse plasma cells and $\gamma \delta \mathrm{T}$ cells (Saini et al., 2014; Douguet et al., 2016b). Similarly, certain lymphocyte subsets, such as follicular B cells, mucosal associated invariant T cells (MAIT), and Th17 cells express IL4I1 (Molinier-Frenkel et al., 2019) (Figure 2).

\section{THE EFFECT OF AMINO-ACID CATABOLIZING ENZYMES ON T-CELL SIGNALING}

Engagement of the TCR by cognate MHC-peptide complexes leads to intracellular signaling, involving a cascade of protein phosphorylation and calcium fluxes that culminates with nuclear translocation of the transcription factors $\mathrm{NF} \kappa \mathrm{B}$, NFAT, and AP1 and rearrangement of the actin and tubulin cytoskeleton. Expression of an activation program is essential for T-cell survival, proliferation, and differentiation. Signals from costimulatory molecules, such as CD28 engagement by B7 proteins or IL-2 binding to its high affinity receptor, amplify TCR signaling and, in parallel, activate the mammalian target of rapamycin (mTOR)C1 pathway, which is often described as a rheostat of T-cell activity, as it is sensitive to numerous environmental cues in addition to co-stimulation. The mTOR kinase controls both the exit from the quiescent state and 


\begin{tabular}{|c|c|c|c|}
\hline \multicolumn{4}{|c|}{$\begin{array}{cl}\text { Arg } & \text { Phe, Cys, Met... } \\
\text { Amino acids } & \text { Gln } \\
\text { Trp } & \text { Transporter, e.g. SLC7A5 (LAT1), SLC1A5 (ACST2), CAT-1 }\end{array}$} \\
\hline \multicolumn{4}{|l|}{$\begin{array}{l}\text { Reinforcement of the T cell } \\
\text { activation program }\end{array}$} \\
\hline $\begin{array}{l}\text { T cell metabolism reprogramming } \\
\text { \& energy production } \\
\text { Redox control } \\
\text { Epigenetic modifications }\end{array}$ & $\begin{array}{l}\text { Diminished TCR signaling } \\
\text { Defective synapse recruitment of PKC } \theta \\
\text { Decreased APC-T cell synapse formation } \\
\text { Activation of rescue processes } \\
\text { e. g. GCN2K (repressor of protein synthesis) } \\
\text { Blockade of cell cycle progression }\end{array}$ & $\begin{array}{l}\text { Decreased: } \\
\text { PLC } y \text { activation and Ca+ flux (Kyn) } \\
\text { Surface } \mathrm{CD} 3 \zeta\left(\mathrm{H}_{2} \mathrm{O}_{2}\right) \\
\text { JAK3/STATS activation (NO) } \\
\text { F-actin polymerization (NO) } \\
\text { Diminution of the Th17/Treg ratio by AHR } \\
\text { (AHR activation by Kyn \& IAA; inhibition of AHR } \\
\text { expression by NO) }\end{array}$ & $\begin{array}{l}\text { 5-HT defect: } \\
\text { Decreased ErK1/2 and IKB } \alpha \text { activation } \\
\text { Reduced T cell mobility in inflamed tissues } \\
\text { Dopamine defect: } \\
\text { Reduced T cell interaction with GC B cells }\end{array}$ \\
\hline $\begin{array}{l}\text { FIGURE } 1 \text { | Role of amino acids } \\
\text { subunits of LAT) is increased upo } \\
\text { pathway which controls protein s } \\
\text { also required for protein synthesis } \\
\text { of histones and ADN (through S- } \\
\text { cells of amino acids and through } \\
\text { enzymes may also interfere with } \\
\text { Some of these effects are listed ir } \\
\text { Figure } 3 \text {. The general effect of ar }\end{array}$ & $\begin{array}{l}\text { Blo } \\
\text { cell activation. The intake of amino ac } \\
\text { hesis and the reprogramming of T cell } \\
\text { the control of the redox balance (thr } \\
\text { nosylhomocysteine production from m } \\
\text { production of several bioactive metab } \\
\text { ell activation by degrading precursors } \\
\text { e yellow and green boxes. For more } \\
\text { o-acid catabolizing enzymes results in }\end{array}$ & $\begin{array}{l}\text { de of } \mathbf{T} \text { cell proliferation and } \mathbf{f} \\
\text { activation. Uptake of amino acids via } \\
\text { ads to the activation of the mammalian } \\
\text { abolism necessary for the full expressio } \\
\text { glutathione tripeptide [GSH]) synthesis } \\
\text { onine). Amino acid catabolizing enzyme } \\
\text { (NO, kynurenine [Kyn], } \mathrm{H}_{2} \mathrm{O}_{2} \text {, etc.) ac } \\
\text { onoamines with costimulatory functions } \\
\text { ed description of the action of amino-a } \\
\text { ckade of T-cell proliferation and function }\end{array}$ & $\begin{array}{l}\text { ions } \\
\text { urface transporters (CAT and the light } \\
\text { th of rapamycin complex } 1 \text { (mTORC1) } \\
\text { he activation program. Amino acids are } \\
\text { cysteine and for epigenetic modifications } \\
\text { erfere with TCR signaling by starving T } \\
\text { at specific steps. Amino-acid catabolizing } \\
\text { h as serotonin (5-HT) and dopamine. } \\
\text { and their derivatives on TCR signaling, see }\end{array}$ \\
\hline
\end{tabular}

TABLE 1 | Characteristics of the amino acid-catabolizing enzymes expressed in the immune system.

\begin{tabular}{|c|c|c|c|c|c|}
\hline Enzyme Acronyme & $\begin{array}{l}\text { Nitric oxide synthase } \\
\text { (inducible, iNOS; } \\
\text { endothelial, eNOS) }\end{array}$ & $\begin{array}{l}\text { Arginase (Arg1 and } \\
\text { Arg2) }\end{array}$ & $\begin{array}{l}\text { Indoleamine } 2,3 \\
\text { dioxygenase (IDO1 and } \\
\text { IDO2) }\end{array}$ & $\begin{array}{l}\text { Tryptophan } 2,3 \\
\text { dioxygenase (TDO) }\end{array}$ & $\begin{array}{l}\text { Interleukin 4-induced } \\
\text { gene } 1 \text { (IL4I1) }\end{array}$ \\
\hline Main substrate & $\mathrm{H}$ & Arginine & & Tryptophan & Phenylalanine \\
\hline Amino acid depletion & No & Yes & Yes & Yes & Yes \\
\hline $\begin{array}{l}\text { Expression in the } \\
\text { immune system }\end{array}$ & Myeloid cells T cells & $\begin{array}{l}\text { Myeloid cells (Arg1) T } \\
\text { cells (Arg2) }\end{array}$ & Myeloid cells & Myeloid cells & $\begin{array}{l}\text { Myeloid cells, B cells, Th17, } \\
\text { MAIT }\end{array}$ \\
\hline $\begin{array}{l}\text { Expression in other } \\
\text { tissues }\end{array}$ & $\begin{array}{l}\text { Gastrointestinal tract, } \\
\text { Lung, CNS (iNOS) } \\
\text { Endothelium (eNOS) }\end{array}$ & $\begin{array}{l}\text { Liver (Arg1) Prostate, } \\
\text { thyroid (Arg2) }\end{array}$ & $\begin{array}{l}\text { Placenta, lung (IDO1) } \\
\text { Placenta, liver (IDO2) }\end{array}$ & Liver, pituitary gland & Testis, brain \\
\hline Localization & Cytosol, granules (iNOS) & $\begin{array}{l}\text { Cytosol, } \mathrm{PMN}^{\star} \text { granules } \\
\text { (Arg1) Mitochondria } \\
\text { (Arg2) }\end{array}$ & Cytosol & Cytosol & Secreted \\
\hline
\end{tabular}

Data on the expression in non-lymphoid tissues were obtained from The Human Protein Atlas. *PMN, polymorphonuclear cell. 


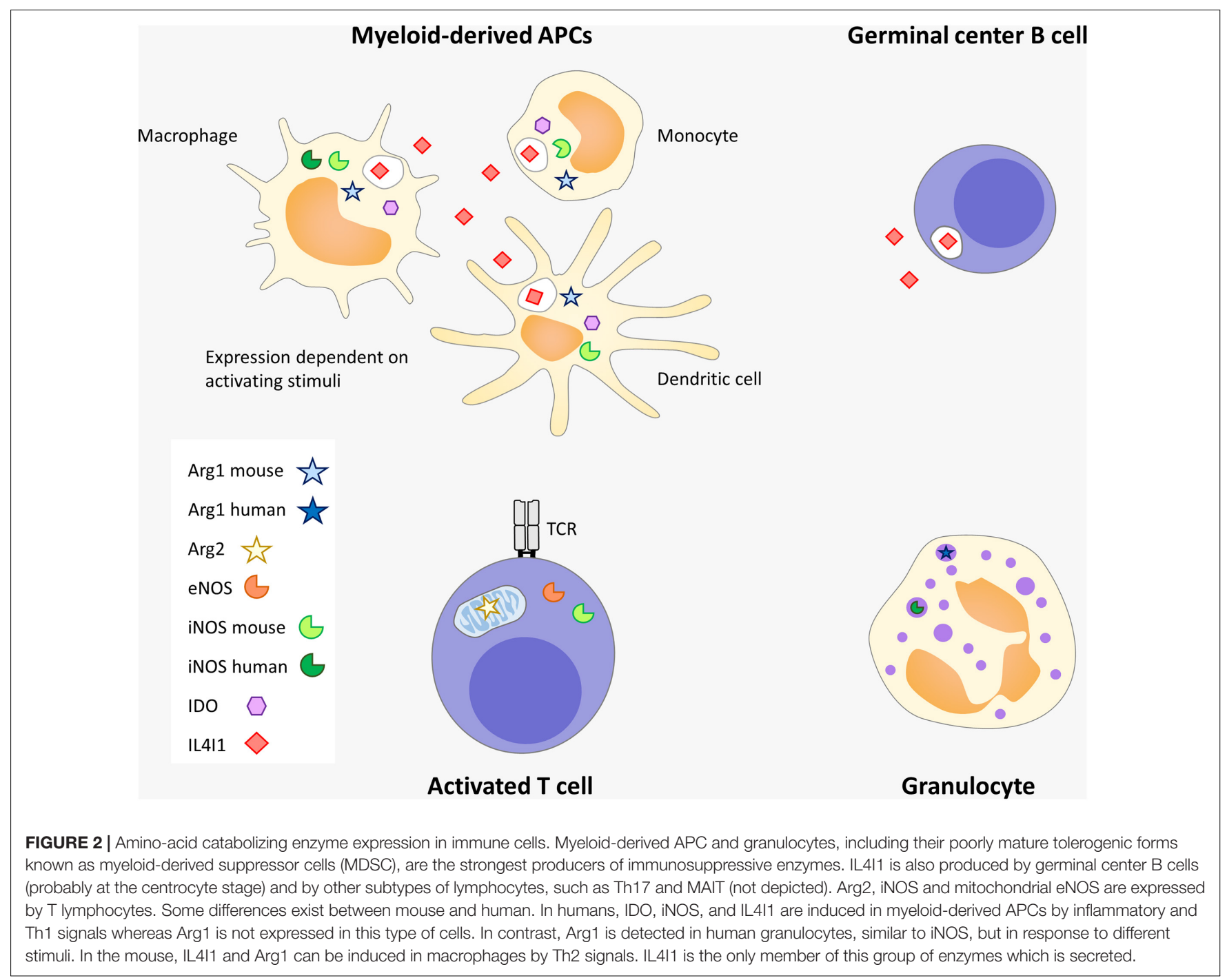

the outcome of T-cell activation and proliferation, including functional differentiation and acquisition of memory properties (Huang et al., 2020).

Certain amino-acid catabolizing enzymes interfere at various points of this signaling cascade (Figure 3). For example, IDO modulates activation of the exchange factor Vav1, which regulates actin polymerization downstream of the TCR by activating the small GTPase Rac1. Indeed, Li et al. (2009) showed a decrease in Vav1 expression and phosphorylation using co-culture systems of $\mathrm{T}$ cells together with IDO expressing cell lines. Consistent with this effect, the $\mathrm{T}$ cells showed defects in actin polymerization after activation, accompanied by a drop in p38 MAP kinase activation ( $\mathrm{Li}$ et al., 2017). More recently, a diminution in the phosphorylation of the $\zeta$ chain of the CD3 complex was also observed (Eleftheriadis et al., 2016). Treatment with the IDO inhibitor 1-methyl tryptophan (1-MT) reversed these inhibitory effects. In mouse lymphocytes, the action of a derivative of Kyn, 3-hydroxyanthranilic acid, reduces PLC $\gamma$ phosphorylation and calcium fluxes (Iken et al., 2012). The activity of IDO has also been implicated in the inhibition of protein kinase $\mathrm{C}(\mathrm{PKC}) \theta$ in experiments using D-1 MT and ectopic expression of IDO1 (Metz et al., 2012).

Decreased downregulation of the $\mathrm{CD} 3 \zeta$ chain has also been reported for IL4I1 partially due to $\mathrm{H}_{2} \mathrm{O}_{2}$ production (Boulland et al., 2007). We used an activation system involving TPH1 cells expressing or not IL4I1 as APCs and showed that IL4I1 inhibits several early signaling kinases downstream of the TCR, including ZAP-70, PLC $\gamma$, and ERK, diminishes calcium fluxes, and reduces the phosphorylation of the p65 subunit of NFKB. This in turn limits the acquisition of the activation markers CD69 and CD25. Unlike other amino-acid catabolizing enzymes, which are intracellular, IL4I1 is secreted by the APC at the interface with the $\mathrm{T}$ cell, leading to reduced synapse formation. Surprisingly, neither the products of the enzymatic reaction nor the absence of Phe is able to recapitulate the effect of IL4I1. In contrast, $\mathrm{H}_{2} \mathrm{O}_{2}$ administered either alone or with $\mathrm{NH}_{4}$ and phenylpyruvate promotes activation of the TCR pathway (Aubatin et al., 2018). Indeed, oxidation by $\mathrm{H}_{2} \mathrm{O}_{2}$ inactivates tyrosine phosphatases involved in the inhibition of TCR signaling (Meng et al., 2002). However, it is important to note that $\mathrm{H}_{2} \mathrm{O}_{2}$ is a highly diffusible 


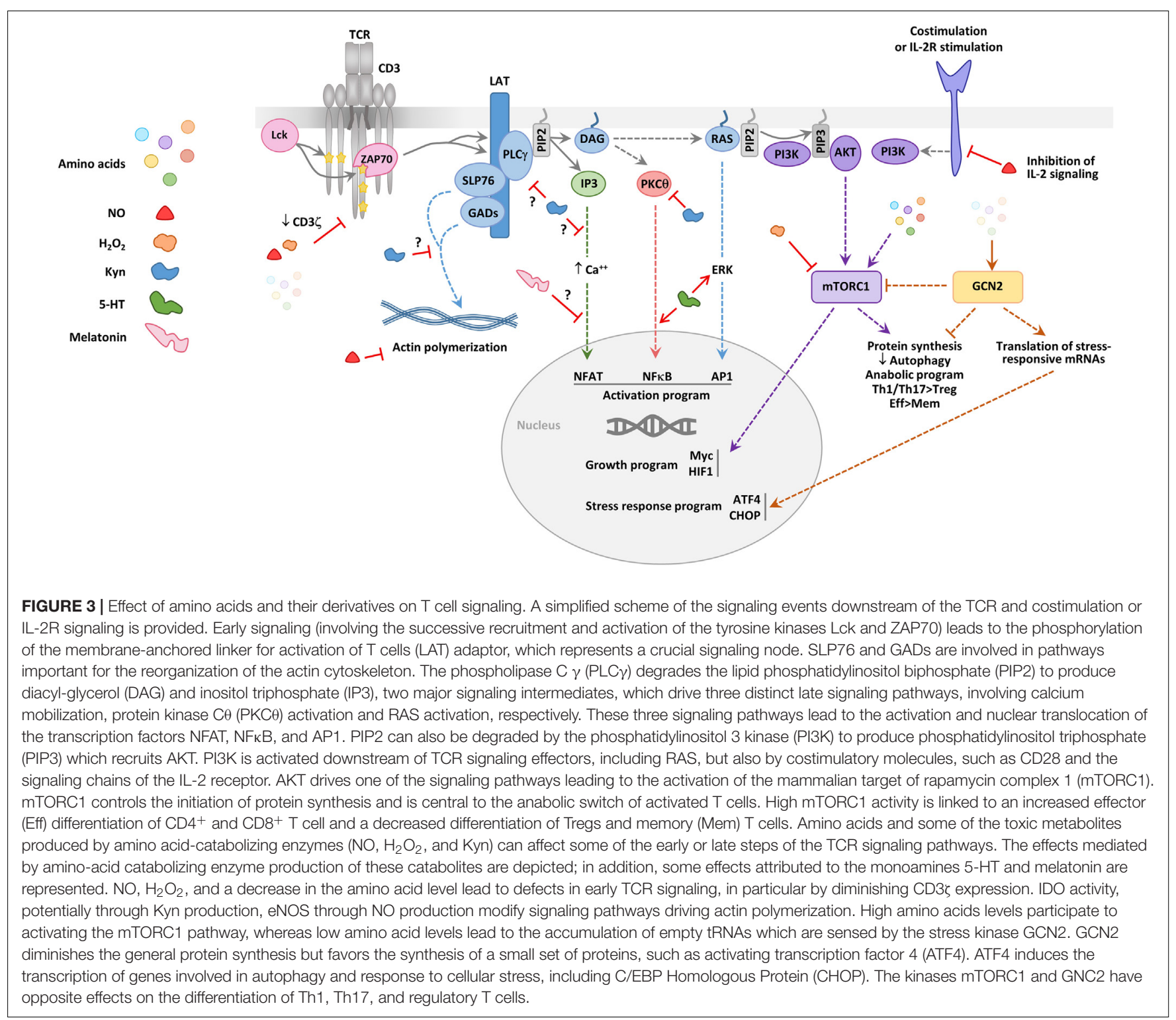

molecule that variably affects $\mathrm{T}$ cells, depending on its local concentration, the duration of exposure, and the antioxidant systems of the $\mathrm{T}$ cell, which may be related to the T-cell subset and state of differentiation (Belikov et al., 2015). Finally, as IL4I1 binds to T lymphocytes, its action on TCR signaling may depend on its interaction with a surface receptor in addition to, or instead of, its enzymatic activity (Aubatin et al., 2018).

$\mathrm{NO}$ and peroxinitrite are powerful agents of protein nitration and nitrosylation which confers them important regulatory functions (García-Ortiz and Serrador, 2018). Macrophagederived NO has long been known to limit T-cell activation by interfering with STAT5 phosphorylation (Bingisser et al., 1998). More recently, the expression of iNOS by eosinophils has also been linked to decreased TCR stimulation (Onyema et al., 2019). The co-culture of iNOS-expressing E1-polarized eosinophils with $\mathrm{T}$ cells expressing a GFP-coupled Nur77 protein, an early TCRresponsive molecule of which the expression directly correlates with the strength of the TCR signal, leads to decreased TCR activation after $\mathrm{CD} 3 / \mathrm{CD} 28$ stimulation in an iNOS-dependent manner. Interestingly, in this study, the level of $\mathrm{CD} 3 \varepsilon$ and $\zeta$ chains decreased in $\mathrm{T}$ cells cultivated with WT eosinophils, but not iNOS-deficient eosinophils, and this correlated with the inhibition of T-cell proliferation by WT eosinophils. Similarly, iNOS has a detrimental effect on the organization of the immune synapse and the secretion of cytotoxic granules (Ferlito et al., 2006). However, NO production by eNOS in contact with the T-cell cytoskeleton is necessary for the correct organization of the immunological synapse and TCR signaling. Indeed, eNOS associates with actin upon TCR engagement to control the organization of the cytoskeleton and the resulting dynamics of signaling micro-clusters. Specifically, NO-mediated S-nitrosylation of F-actin residue Cys374 prevents actin binding to profilin 1, thus limiting actin polymerization. The resulting traction of the micro-clusters fosters the localization of PKC- $\theta$ 
to the center of the immune synapse, thus facilitating its activation (García-Ortiz et al., 2017). Overall, these data suggest that different quantities, localization, and/or kinetics of $\mathrm{NO}$ production can have opposing effects on T-cell activation.

Arginine deficiency is well-known to block T cell proliferation (Rodriguez et al., 2017), whereas a sufficient level of arginine is necessary for the long-term survival and anti-tumor activity of $\mathrm{T}$ cells in vivo, independently of mTOR signaling. Impairment of early TCR signaling has been documented for Arg1. Depletion of arginine by macrophage-derived Arg1 or the growth of $\mathrm{T}$ cells in arginine-deprived medium leads to downregulation of the CD3 $\zeta$ chain (Rodriguez et al., 2003). This hallmark of T-cell dysfunction can also be observed in cancer patients in association with increased plasma activity of Arg1 released by myeloid-derived suppressor cells (MDSCs) (Rodriguez et al., 2009). Arginine-starved Jurkat T cells are still able to up-regulate IL-2 receptor chains and secrete IL-2 (Taheri et al., 2001), but are blocked at the G0-G1 transition of the cell cycle. This is due to decreased mRNA stability and a diminished translational rate of cyclin D3 and cyclin-dependent kinase 4 (Rodriguez et al., 2007). Cyclin D3 mRNA instability has been shown to result from a decrease in the level of the RNA-binding protein $\mathrm{HuR}$ (Rodriguez et al., 2010). These effects are all dependent on the general control non-derepressible 2 (GCN2) kinase (Rodriguez et al., 2007), an amino-acid sensor activated by uncharged tRNA molecules that inhibits eukaryotic initiation factor- $2 \alpha$ (eIF $2 \alpha$ ) to repress protein synthesis. A pegylated form of Arg1 (PEG-Arg) has been used in vitro to limit the growth of cancer cells due to their dependence on arginine and is now being tested for its therapeutic effect in cancer (currently seven clinical trials ${ }^{1}$ ). However, PEG-Arg simultaneously limits arginine availability to $\mathrm{T}$ cells, thus blocking cell-cycle progression, despite the fact that it does not affect the acquisition of activation markers in vitro (Fletcher et al., 2015). In vivo administration of PEG-Arg induces the accumulation of granulocytic MDSCs via GCN2 activation. These MDSCs themselves show increased expression of Arg1 and are responsible for the inhibition of T-cell proliferation. Their accumulation is associated with enhanced tumor growth (Fletcher et al., 2015), suggesting that arginine starvation is a risky strategy for the treatment of cancer.

Similar to the situation for NOS, T lymphocytes themselves express the mitochondrial isoform of Arg (Arg2), showing a significant increase after activation. A recent analysis compared the proteome and metabolome of 72-h-activated and freshly isolated human naïve T cells. Arg2 transcription was higher in activated T cells, whereas among 429 differential metabolites, the levels of arginine, ornithine, and $\mathrm{N}$-acetylornithine were lower, indicating that activation-induced Arg2 is metabolically active (Geiger et al., 2016). Murine T cells lacking Arg2 show faster and stronger activation marker dynamics, whereas their proliferative activity is not affected. In vivo, the lack of Arg2 allows the persistence of antitumor $\mathrm{CD}^{+} \mathrm{T}$ cells and facilitates their differentiation into central memory $\mathrm{T}$ cells (Líndez et al., 2019). Arg2 is not expressed in peripheral blood regulatory $\mathrm{T}$ cells (Tregs), but its expression is induced by TCR stimulation

${ }^{1}$ www.clinicaltrial.gov and it is detected in Tregs from normal and inflamed skin. Arg2 expression by Tregs decreases mTOR signaling and enhances their suppressive activity (Lowe et al., 2019).

The T-cell inhibitory effect of arginine depletion is limited by the addition of citrulline, which can be endogenously converted into arginine (Bansal et al., 2004). T-cell activation induces the expression of the transporter LAT1 even under limiting arginine concentrations, allowing citrulline uptake by $\mathrm{T}$ cells. In a recent study, Werner et al. (2017) showed that arginine depletion induces both arginosuccinate synthase and arginosuccinate lyase, the two enzymes which allow the synthesis of arginine from citrulline, in T cells.

As previously mentioned for Tregs, certain effects of aminoacid catabolizing enzymes on $\mathrm{T}$ cells have been attributed to their inhibition of the mTOR pathway. Activation of naive human $\mathrm{T}$ cells in the presence of IL4I1 limits the activation of the mTORC1 targets ribosomal S6 protein and p70S6K (Cousin et al., 2015). In HeLa cells, induction of IDO by interferon (IFN) $\gamma$ depletes tryptophan and represses phosphorylation of p70S6K. The IDO1 inhibitor 1D-MT can reverse this inhibition, independently from GCN2 (Metz et al., 2012). In addition to its indirect effects on signaling pathways that are sensitive to aminoacid or kyn levels, IDO1 can directly interfere with intracellular signaling by recruiting the tyrosine phosphatases SHP1 and SHP2 through its immunoreceptor tyrosine-based inhibitory motifs (Pallotta et al., 2011). This function has been demonstrated in plamacytoid DCs (pDCs), in which IDO1 shifts from the cytosol to early endosomes to perform its signaling activity that is associated with amplification of a tolerogenic program (Iacono et al., 2020). Other amino-acid catabolizing enzymes may have properties independent from their catabolic activity, but this has not yet been explored.

Moreover, depending on the context, the simultaneous expression of these enzymes in the same cell or same microenvironment may modify their T-cell regulatory properties. This is known for the well-described co-expression of Arg1 and iNOS in cancer, which allows peroxinitrite formation, as stated above. IDO1 and Arg1 can also be expressed in the same tumor microenvironment. It has been demonstrated that TGF $\beta$ induces Arg1 expression in DCs, which is necessary for and followed by IDO1 expression. Polyamine production from the Arg1 catabolite ornithine favors Src kinase activation and the phosphorylation of IDO1, allowing its immunosuppressive signaling (Mondanelli et al., 2017). Stimuli produced by the anti-tumor response, such as IFN $\gamma$, are likely to induce contemporaneous expression of IDO1, IL4I1, and iNOS, with still undetermined consequences.

\section{CONSEQUENCES OF AMINO-ACID CATABOLIZING ENZYME ACTIVITY ON T-CELL DIFFERENTIATION AND FUNCTION}

Most amino-acid catabolizing enzymes, including IDO1 and IL4I1, decrease T-cell proliferation and modify the balance of effector versus regulatory T-cell differentiation (Figure 4). 


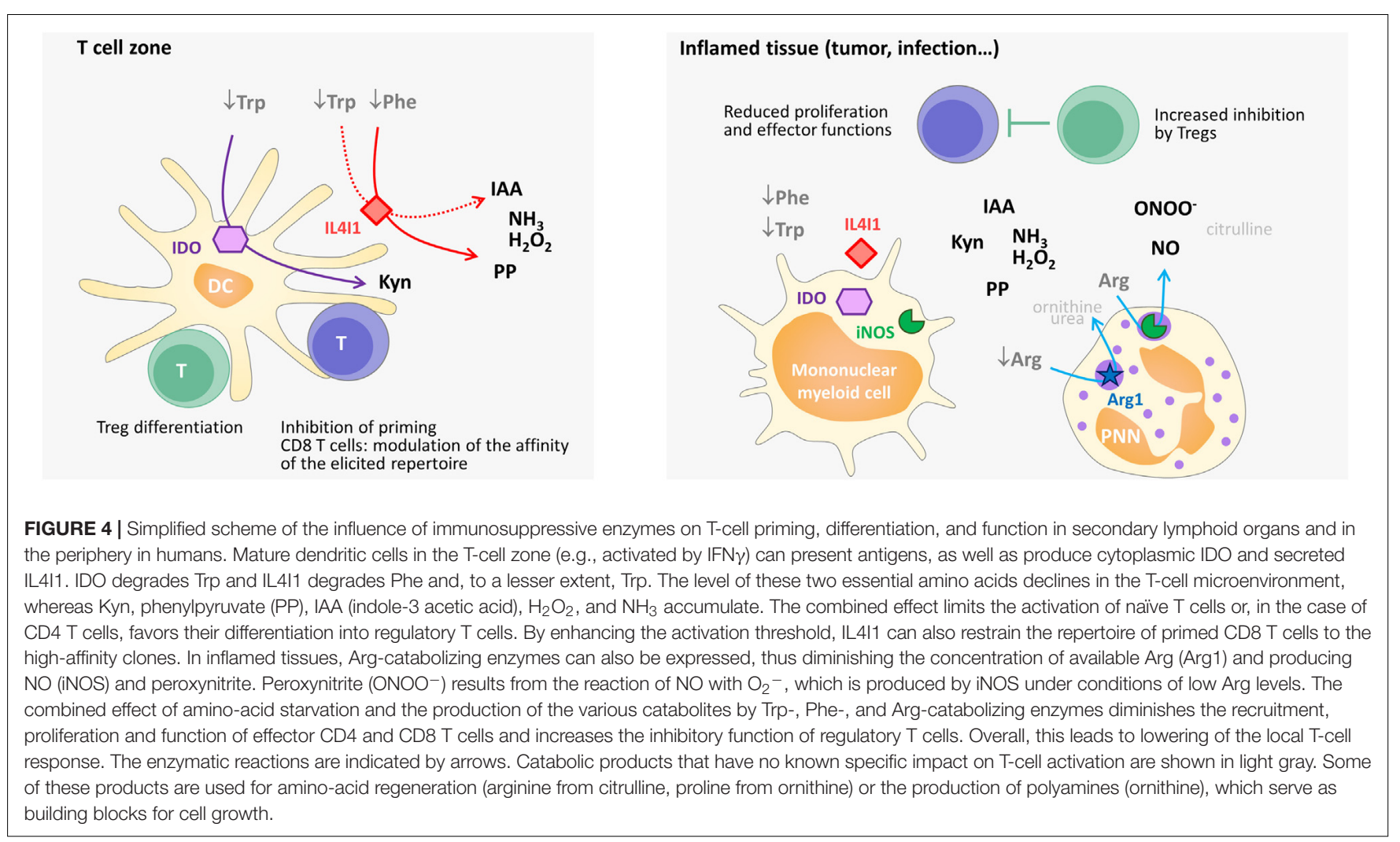

Plasmacytoid dendritic cells stimulated by CpG induce IDO activity, which stabilizes the suppressor phenotype of Tregs, while simultaneously blocking the IL-6 expression required for Th17 cell differentiation (Baban et al., 2009). During fungal infection of mice with Paracoccidioides brasiliensis, the absence of IDO1 is associated with an increased influx of Th17 cells to the infected lung and a concomitant reduction of the number of Th1 and Treg cells (de Araújo et al., 2017). Kyns, which are produced both by IDO and TDO, have been shown to bind to the aryl hydrocarbon receptor (AHR), a highly conserved ligand-activated transcription factor involved in controlling the balance of Treg versus Th17 differentiation (Mezrich et al., 2010; Opitz et al., 2011). Although certain AHR ligands promote the differentiation of Th17 cells, AHR activation by Kyns leads to Treg generation (Mezrich et al., 2010). In addition, tryptophan depletion can enhance the suppressive functions of Tregs by excluding PKC $\theta$ from the immune synapse, thus inhibiting its signaling activity (Zanin-Zhorov et al., 2010; Metz et al., 2012).

Differentiation of naïve $\mathrm{CD}^{+}{ }^{+} \mathrm{T}$ cells in the presence of IL4I1 also skews their polarization toward Tregs, whereas it does not substantially affect Th17 differentiation. This effect appears to involve diminution of mTORC1 signaling (Cousin et al., 2015). However, it has also been recently observed that IL4I1 degradation of tryptophan [a minor substrate in comparison to phenylalanine (Boulland et al., 2007)] produces indole derivatives that can activate the AHR pathway (Sadik et al., 2020; Zhang et al., 2020). Finally, IL4I1 modulates the priming of $\mathrm{CD}^{+} \mathrm{T}$ cells. Indeed, the absence of IL4I1 lowered the activation threshold of cognate $\mathrm{CD} 8^{+} \mathrm{T}$ cells in a mouse model of acute infection with the lymphocytic choriomeningitis virus, leading to extension of the responding repertoire to low-affinity clones and increased memory T-cell differentiation. Thus, IL4I1 may represent a mechanism to restrain T-cell activation to high-affinity $\mathrm{CD} 8^{+}$ T-cell clones (Puiffe et al., 2020).

Arg1 produced by MDSCs has also been suggested to play a role in Th17 differentiation. Indeed, ROR $\gamma \mathrm{T}$ and IL-17A expression decrease in T cells cultured with MDSCs treated with the Arg1 inhibitor Nor-NOHA (Wu et al., 2016). Consistent with this observation, mice with a conditional deletion of Arg1 in myeloid cells show decreased expression of IL-17A in the colorectum during experimentally induced colitis (Ma et al., 2020). High concentrations of NO provided by the NO donor NOC-18 can suppress the proliferation and function of polarized murine and human Th17 cells by inhibiting the expression of AHR (Niedbala et al., 2011). In accordance with this result, iNOS-deficient mice exhibit enhanced Th17 cell differentiation but no changes in Th1 or Th2 polarization (Yang et al., 2013). Conversely, the use of NOC-18 induces the proliferation and sustained survival of $\mathrm{CD} 4^{+} \mathrm{CD} 25^{-} \mathrm{T}$ cells, which acquire the expression of $\mathrm{CD} 25$ but not Foxp3 and present regulatory functions (Niedbala et al., 2007). In sharp contrast with these findings, physiological NO levels produced by the MDSCs of cancer patients or endogenously by $\mathrm{CD} 4^{+} \mathrm{T}$ cells expressing iNOS can induce and stabilize the Th17 phenotype (Obermajer et al., 2013). Mouse $\gamma \delta \mathrm{T}$ cells also express iNOS, in particular following stimulation by inflammatory cytokines 
(Douguet et al., 2018). The enzyme is essential for promoting optimal IL-2 production and proliferation of $\gamma \delta \mathrm{T}$ cells, but drives IL-17 production, which is associated with pro-tumor properties in a murine model of melanoma (Douguet et al., 2016a,b). These findings illustrate the dual role of NO on T cell activation at the level of T-cell differentiation, depending on its concentration.

\section{OTHER AMINO ACIDS IMPORTANT FOR T-CELL SIGNALING AND ACTIVATION}

Several other amino acids are involved in controlling T-cell function.

Recent metabolomics data have provided information on the importance of methionine uptake during T-cell activation. TCR engagement drives increased flow through the methionine cycle, which supplies the lymphocyte with methyl donors necessary for epigenetic modifications, as well as the first amino acid in protein synthesis (Martínez et al., 2017). Indeed, TCR stimulation upregulates and sustains both the transport of methionine and the expression of the enzymes involved in the production of S-adenosylhomocysteine from methionine. S-adenosylhomocysteine is necessary for histone methylation (Sinclair et al., 2019). Thus, although no specific enzyme that catabolizes methionine has been yet described, modifications of methionine availability should have important repercussions on the ability of $\mathrm{T}$ cells to respond to an antigenic challenge. Cancer cells have been recently shown to be metabolically dependent on methionine (Wang et al., 2019) and to avidly uptake this amino acid through the SLC43A2 transporter (Bian et al., 2020). Depletion of the tumor microenvironment of this amino acid by tumor cells may decrease its availability to infiltrating $\mathrm{T}$ lymphocytes. Consistent with this hypothesis, the absence of methionine decreases the $\mathrm{CD}^{+}{ }^{+} \mathrm{T}$-cell immune response by dysregulating the transcription of essential genes due to deficient epigenetic reprogramming (Bian et al., 2020).

In the oxidizing environment of the extracellular space, cysteine exists primarily in its oxidized disulfide-bonded form cystine. Cysteine is an essential amino acid for $\mathrm{T}$ cells, as they are not equipped for its synthesis. Although cysteine and cystine are not required for early T-cell activation, their role in DNA and protein synthesis, proliferation, and cytokine secretion of antigen-stimulated $\mathrm{T}$ cells was shown long ago to be controlled by APCs through the extracellular release of cysteine (Angelini et al., 2002). Whereas naïve T cells cannot import cysteine or cystine, activated human $\mathrm{T}$ cells express transporters for both forms (Levring et al., 2012). Cysteine is the rate-limiting substrate for the synthesis of the glutathione tripeptide (GSH) which is required for T-cell proliferation and effector functions (Levring et al., 2015; Mak et al., 2017). Indeed, GSH protects signaling proteins from damage caused to cysteine and methionine residues by reactive oxygen species through its antioxidative activity. For example, GSH maintains the conformation of the membrane-anchored linker for activation of T cells (LAT) (Gringhuis et al., 2002) and supports mTOR and NFAT activation to drive the reprogramming of T-cell energy metabolism (Mak et al., 2017). Tumor-infiltrating MDSCs can limit $\mathrm{T}$ cell antitumor activity by consuming cystine and sequestering cysteine (Srivastava et al., 2010).

Glutamine is the most abundant free amino acid in the body. Glutaminolysis is a highly important source of biosynthetic precursors and energy in active T cells. T-cell activation strongly increases glutamine import and stimulates glutaminolysis. ERK and mTORC1 signaling are involved in promoting the expression of transporters and enzymes required for glutamine metabolism in $\mathrm{T}$ cells. As for cysteine or arginine, the absence of glutamine blocks T-cell proliferation but not the acquisition of early activation markers (Carr et al., 2010). The uptake of glutamine by its major transporter SLC1A5 (ACST2) is required for leucine import by the glutamine/leucine antiporter (see below) and mTORC1 activation (Nicklin et al., 2009), thereby promoting $\mathrm{CD}^{+}{ }^{+}$T-cell differentiation into Th1 and Th17 cells (Nakaya et al., 2014). The bacterial enzyme asparaginase, commonly used as an anticancer agent in lymphoblastic leukemia, catalyzes the deamination of asparagine and, to a lesser extent, glutamine, to aspartic acid and glutamic acid, respectively (Derman et al., 2020). The absence of asparagine affects T-cell activation and IL-2 production through inhibition of the mTORC1 pathway (Torres et al., 2016). Asparaginase kills tumor cells via combined asparagine and glutamine deprivation but its indications are limited by severe acute side effects and the induction of profound immunosuppression (Kim et al., 2015; Song et al., 2017).

Alanine is an amino acid that can be synthesized from pyruvate. Nevertheless, recent data have shown that lymphocytes depend on the import of extracellular alanine, which is vital for the transition from quiescence to activation of both naïve and memory T cells. Indeed, in the absence of extracellular alanine, early T-cell activation is delayed and the metabolic changes induced by activation are impaired (Ron-Harel et al., 2019).

Finally, leucine is the most common proteinogenic amino acid. The T-cell uptake of leucine involves the SLC7A5-SLC3A2 (LAT1-CD98) transporter, which imports branched amino acids while exporting glutamine (Fuchs and Bode, 2005). Along with arginine, leucine is a major activator of the mTORC1 complex, thus contributing to the costimulatory signal (Ananieva et al., 2016). The use of the leucine competitor $\mathrm{N}$-acetyl-leucine-amide blocks T-cell activation, leading to anergy by limiting mTOR activation (Zheng et al., 2009). Consequently, leucine is involved in the differentiation of $\mathrm{CD}^{+}{ }^{+}$and $\mathrm{CD} 8^{+} \mathrm{T}$ cells. For example, it has been shown that leucine addition reverses the ghrelininduced inhibition of iTh17 cell differentiation through mTORC1 activation (Xu et al., 2015).

\section{AMINO-ACID DERIVED COMPOUNDS}

Certain neuroactive monoamines, such as dopamine, serotonin, and melatonin, are derived from enzymatic modifications of Trp, Tyr, or Phe. These monoamines are mainly known as neurotransmitters and signal through specific G-coupled receptors. More recent work demonstrates that they can also influence T-cell differentiation and function. Thus, amino-acid 
catabolizing enzymes may also affect the T-cell response by decreasing the availability of these compounds.

Serotonin (hydroxytryptamine, 5-HT) is formed by the hydroxylation of Trp followed by decarboxylation. Certain immune-cell populations, including mast cells and $\mathrm{T}$ lymphocytes, can synthesize and release 5-HT, although $95 \%$ of the 5 -HT in our body is produced by the nervous system of the gastrointestinal tract. The initial evidence that 5-HT has an influence on $\mathrm{T}$ cells was reported 35 years ago in rats (Steplewski and Vogel, 1985). 5-HT is an important neurotransmitter and its role in inflammation and immunity has been mainly studied in patients with psychiatric or neurodegenerative diseases. $\mathrm{T}$ cells produce 5 -HT as an autocrine factor that acts through the $5-\mathrm{HT}_{3}$ receptor. Such production may facilitate T-cell infiltration in inflamed tissues by regulating $\mathrm{T}$-cell responsiveness to chemokines (Magrini et al., 2011). In vitro addition of 5-HT to T-cell cultures induces rapid phosphorylation of ERK1/2 and $\mathrm{IkB} \alpha$ through stimulation of the $5-\mathrm{HT}_{7}$ receptor (LeónPonte et al., 2007) and may also induce $\mathrm{Ca}^{++}$release (Genius et al., 2015). 5-HT has been suggested to play a protective role in multiple sclerosis by attenuating the proliferation of and cytokine production by Th1 and Th17 cells and by favoring the expansion of $\mathrm{CD}_{3}{ }^{+}$Foxp $^{+}$T-regulatory lymphocytes, which secrete IL-10 (Sacramento et al., 2018).

The pineal gland synthesizes and releases melatonin $(\mathrm{N}$ acetyl-5-methoxytryptamine) in response to decreased light. Melatonin is produced from Trp via 5-HT and principally acts as a regulator of circadian rhythms. As such, it may be involved in adjusting the immune system to circadian and seasonal fluctuations (Farez et al., 2016). However, as for 5-HT, the gastrointestinal tract is the largest producer of melatonin and several other extra-pineal sites contain melatonin-producing cells, including $\mathrm{T}$ cells. The biological effects of melatonin mainly depend on the activation of the specific G-coupled receptors MT1 and MT2, which are expressed by cells of the immune system (Farez et al., 2016). Melatonin has been suggested to participate in T-cell activation and protection from activationinduced cell death (Carrillo-Vico et al., 2005; Pedrosa et al., 2010). Melatonin also exhibits potent antioxidant properties, both direct and indirect, through the modulation of antioxidant gene transcription (Acuña-Castroviejo et al., 2014), which may interfere with T-cell activation. Melatonin is considered to be an anti-inflammatory agent (Tarocco et al., 2019) and is suspected to play a role in autoimmune diseases. The most important evidence was provided by a study of Farez et al., which showed a correlation between relapses of multiple sclerosis and decreased melatonin levels associated with increased exposure to sunlight (Farez et al., 2015). The effect of melatonin was attributed to MT1 stimulation and activation of the ERK1/2 kinases, leading to expression of the transcriptional repressor NFIL3, which blocks the differentiation of pathogenic Th17 cells. Concomitantly, melatonin favored the generation of protective Tr1 cells and their production of IL-10 via ROR- $\alpha$ activation of the $I l 10$ promoter.

Catecholamines, i.e., dopamine, noradrenaline, and adrenaline, are other neuroactive molecules that can influence the immune response. These molecules are derived from
Phe via tyrosine, which is hydrolyzed to form the L-DOPA precursor. Lymphocytes can produce catecholamines, in particular dopamine (Bergquist et al., 1994). Catecholamines may participate in the fine-tuning of T-cell responses, but their effects have thus far not been extensively evaluated (Hodo et al., 2020). Five G-protein-coupled receptors (classified in the DR1-like and DR2-like families) mediate the effect of dopamine. TCR stimulation induces the expression of these receptors at the surface of human CD4 $\mathrm{T}$ cells (Kustrimovic et al., 2014). It has been suggested that dopamine diminishes T-cell activation via inhibition of Erk1/2 phosphorylation and reduced nuclear translocation of NFKB (Strell et al., 2009) or by limiting the expression of the upstream tyrosine kinases Lck and Fyn (Ghosh et al., 2003) and induces T-cell quiescence by up-regulating Krüppel-like factor-2 expression (Sarkar et al., 2006). However, varying doses of dopamine and stimulation of different dopamine receptors may determine divergent effects on $\mathrm{T}$ cells (Hodo et al., 2020). For example, in vivo data from mouse models deficient for DR3 (D2-like receptor) suggest that activation of this receptor favors Th1/Th17 but limits Th2 differentiation of naïve CD4 T cells (Contreras et al., 2016). Finally, one of the most exciting findings has been that dopamine secreted by follicular helper $\mathrm{T}$ cells facilitates the expression of the costimulatory molecule ICOS ligand (ICOSL) at the surface of germinal center B cells (Papa et al., 2017). This translates into an increase in the molecular dialogue between the two types of cells and the acceleration of B-cell exit from the germinal center (Papa et al., 2017). Interestingly, both Phe and L-DOPA are high-affinity substrates of IL4I1 [(Mason et al., 2004) and our unpublished data]. Thus, catabolism of their precursors by IL4I1 may reduce the availability of catecholamines, with a potential impact on the regulation of $\mathrm{T}$-cell activation and function.

\section{BACTERIAL-HOST INTERACTIONS IN THE PRODUCTION OF AMINO-ACID DERIVED METABOLITES}

Several amino-acid catabolizing enzymes have a very ancient evolutionary origin, as they are detected in bacteria, in which they participate in maintaining the nutrient niche along with other metabolic enzymes. Their activity is essential for maintaining the equilibrium of the microflora and also influences the availability of amino acids and amino-acid derivatives to the host (Gao et al., 2018). Notably, a substantial amount of Trp absorbed from the diet is metabolized by gut microbes, which convert it into various compounds, including AHR-activating indole derivatives with T-cell inhibiting properties (Wojciech et al., 2020). As an illustration of the importance of such metabolism, the levels of AHR ligands produced by the gut microbiota have been recently shown to be reduced in patients with celiac disease (Lamas et al., 2020). Conversely, the activity of host amino-acid catabolizing enzymes can influence the availability of amino acids to the microbiota, with consequences on local inflammation, as shown by the role of host Arg1 on the composition of microbiota and bacterial production of protective polyamines 
in a mouse model of inflammatory bowel disease (Baier et al., 2020). Thus, the microbiota participates in local immune homeostasis through its amino-acid catabolizing activity and alterations of such activity can lead to immunopathology. It is also probable that microbial amino-acid catabolizing enzymes have an impact on host immunity at non-mucosal sites, as the gastrointestinal tract requires amino acids for the production of immunoregulatory monoamines (melatonin, 5-HT). In certain instances, the activity of the bacterial enzymes may even surpass that of host amino-acid catabolizing enzymes. Indeed, it has been observed that the gut microbiota has a major influence on the level of circulating Trp, indole compounds, and serotonin (Wikoff et al., 2009; Clarke et al., 2013; O’Mahony et al., 2015).

\section{CONCLUSION AND PERSPECTIVES}

Aside from serving as the basic building blocks of proteins, amino acids can contribute to many critical processes in growing $\mathrm{T}$ cells, including energy metabolism, nucleotide synthesis, epigenetic remodeling, and redox control. $\mathrm{T}$ cells require prompt and massive intake of amino acids upon activation. They are thus equipped to sense amino-acid levels, directly and indirectly, via signaling molecules, some of which, like mTOR, control pathways downstream of TCR, costimulatory molecule, and cytokine receptor signaling. Their dependence on external amino-acid import makes $\mathrm{T}$ cells highly vulnerable to variations in their extracellular level. Several of the aminoacid catabolizing enzymes expressed in the proximal T-cell microenvironment play an important role in the control of T-cell activation, proliferation, and differentiation by regulating the level of essential and semi-essential amino acids. This effect can be coupled with the production of bioactive catabolites, which also regulate fundamental processes of activated $\mathrm{T}$ cells. These complimentary pathways to control T-cell functionality can become imbalanced in pathological situations, such as during cancer development, in which the expression of amino-acid catabolizing enzymes diminishes the quality and strength of the antitumor immune response.

Indoleamine 2,3, dioxygenase, Arg1 and iNOS have received much attention in the last 20 years. However, some aspects of their action have still not been completely elucidated. It is still not totally understood how they can affect the signaling of the $\mathrm{T}$ cell, while they are intracellular and produced by APCs. IL4I1 has been more recently identified as an immunosuppressive enzyme and its physiological role is still only partially characterized. As it is a secreted enzyme, its action may be mediated by mechanisms different from those of the intracellular enzymes. Given that several amino acids play a role in $\mathrm{T}$ cell activation, other unidentified amino-acid catabolizing enzymes may be involved in T-cell regulation. Finally, the interplay between different enzymes coexpressed by the same cell or in the same microenvironment has only been partially defined. It would be also worth investigating whether it is possible to reverse the effect of these enzymes on TCR signaling using the recently developed specific inhibitors.

Another set of questions remains concerning the action of amino acid catabolizing enzymes on the level of amino-acid derived monoamines that play a role in the neuro-immune axis. The expression of some of these enzymes at discrete sites of monoamine production may regulate specific functions. For example, IL4I1 is highly expressed by centrocytes, i.e., B cells that interact with follicular $\mathrm{T}$ helper cells during germinal center maturation of the B-cell response (Caron et al., 2009; Victora et al., 2010). In addition to inhibiting TCR signaling, this expression may interfere with dopamine production by the $\mathrm{T}$ cells and stop the dopamine-induced positive feedback loop that fosters B cell differentiation.

Whilst the role of amino acid catabolizing enzymes has been explored in the pathophysiology of various conditions, no major genetic alterations of these enzymes have been yet reported to be associated with human disease. However, further consideration should be given to patients affected by diseases in which a role of amino-acid catabolizing enzymes has been firmly demonstrated. Notably, in the context of cancer, treatments have been developed that target amino-acid metabolism of the tumor cells. These strategies can show considerable short-term efficacy. However, they carry a risk of facilitating relapse by dampening the antitumor T-cell response. This is especially important in the era of immunotherapy with immune checkpoint inhibitors and chimeric antigen receptor $\mathrm{T}$ cells (CAR-T). Indeed, Ninomiya et al. showed that CD19-targeted CAR-T lose their capacity to inhibit tumor cell growth in a xenograft lymphoma model when they express IDO (Ninomiya et al., 2015). Consistent with these results, IL4I1 expression in human melanoma has been recently associated with resistance to anti-PD-L1 (Sadik et al., 2020). Specific inhibitors of amino-acid catabolizing enzymes may thus enhance the efficacy of immune checkpoint inhibitors and CAR-T, whereas combining these new therapies with treatments targeting tumor metabolism may not be a valid strategy. Results from clinical trials should shed new light on these issues.

\section{AUTHOR CONTRIBUTIONS}

VM-F and FC conceived and wrote the manuscript. Both authors contributed to the article and approved the submitted version.

\section{FUNDING}

This work was supported by a grant from the Fondation BMS pour la Recherche en Immuno-Oncologie to FC.

\section{ACKNOWLEDGMENTS}

The manuscript has been professionally corrected by a native English speaker from the scientific editing and translation company, Alex Edelman and Associates. 


\section{REFERENCES}

Acuña-Castroviejo, D., Escames, G., Venegas, C., Díaz-Casado, M. E., LimaCabello, E., López, L. C., et al. (2014). Extrapineal melatonin: sources, regulation, and potential functions. Cell. Mol. Life Sci. 71, 2997-3025. doi: 10.1007/s00018-014-1579-2

Ananieva, E. A., Powell, J. D., and Hutson, S. M. (2016). Leucine metabolism in $\mathrm{T}$ cell activation: mTOR signaling and beyond. Adv. Nutr. Int. Rev. J. 7, 798S-805S.

Angelini, G., Gardella, S., Ardy, M., Ciriolo, M. R., Filomeni, G., Di Trapani, G., et al. (2002). Antigen-presenting dendritic cells provide the reducing extracellular microenvironment required for $\mathrm{T}$ lymphocyte activation. Proc. Natl. Acad. Sci. U.S.A. 99, 1491-1496. doi: 10.1073/pnas.0226 30299

Aubatin, A., Sako, N., Decrouy, X., Donnadieu, E., Molinier-Frenkel, V., and Castellano, F. (2018). IL4-induced gene 1 is secreted at the immune synapse and modulates TCR activation independently of its enzymatic activity. Eur. J. Immunol. 48, 106-119. doi: 10.1002/eji.201646769

Baban, B., Chandler, P. R., Sharma, M. D., Pihkala, J., Koni, P. A., Munn, D. H., et al. (2009). IDO activates regulatory $\mathrm{T}$ cells and blocks their conversion into Th17-Like T cells. J. Immunol. 183, 2475-2483. doi: 10.4049/jimmunol. 0900986

Baier, J., Gänsbauer, M., Giessler, C., Arnold, H., Muske, M., Schleicher, U., et al. (2020). Arginase impedes the resolution of colitis by altering the microbiome and metabolome. J. Clin. Invest. 130, 5703-5720. doi: 10.1172/jci1 26923

Bansal, V., Rodriguez, P., Wu, G., Eichler, D. C., Zabaleta, J., Taheri, F., et al. (2004). Citrulline can preserve proliferation and prevent the loss of CD3 $\zeta$ chain under conditions of low Arginine. JPEN J. Parenter. Enteral Nutr. 28, 423-430. doi: 10.1177/0148607104028006423

Belikov, A. V., Schraven, B., and Simeoni, L. (2015). T cells and reactive oxygen species. J. Biomed. Sci. 22:85.

Bergquist, J., Tarkowski, A., Ekman, R., and Ewing, A. (1994). Discovery of endogenous catecholamines in lymphocytes and evidence for catecholamine regulation of lymphocyte function via an autocrine loop. Proc. Natl. Acad. Sci. U.S.A. 91, 12912-12916. doi: 10.1073/pnas.91.26.12912

Bian, Y., Li, W., Kremer, D. M., Sajjakulnukit, P., Li, S., Crespo, J., et al. (2020). Cancer SLC43A2 alters T cell methionine metabolism and histone methylation. Nature 585, 277-282. doi: 10.1038/s41586-020-2682-1

Bingisser, R. M., Tilbrook, P. A., Holt, P. G., and Kees, U. R. (1998). Macrophagederived nitric oxide regulates $\mathrm{T}$ cell activation via reversible disruption of the Jak3/STAT5 signaling pathway. J. Immunol. 160, 5729-5734.

Boulland, M.-L., Marquet, J., Molinier-Frenkel, V., Möller, P., Guiter, C., Lasoudris, F., et al. (2007). Human IL4I1 is a secreted 1-phenylalanine oxidase expressed by mature dendritic cells that inhibits T-lymphocyte proliferation. Blood 110, 220-227. doi: 10.1182/blood-2006-07-036210

Braun, D., Longman, R. S., and Albert, M. L. (2005). A two-step induction of indoleamine 2,3 dioxygenase (IDO) activity during dendritic-cell maturation. Blood 106, 2375-2381. doi: 10.1182/blood-2005-03-0979

Caron, G., Le Gallou, S., Lamy, T., Tarte, K., and Fest, T. (2009). CXCR4 expression functionally discriminates centroblasts versus centrocytes within human germinal center B cells. J. Immunol. 182, 7595-7602. doi: 10.4049/ jimmunol.0804272

Carr, E. L., Kelman, A., Wu, G. S., Gopaul, R., Senkevitch, E., Aghvanyan, A., et al. (2010). Glutamine uptake and metabolism are coordinately regulated by ERK/MAPK during T lymphocyte activation. J. Immunol. 185, 1037-1044. doi: 10.4049/jimmunol.0903586

Carrillo-Vico, A., Lardone, P. J., Fernández-Santos, J. M., Martín-Lacave, I., Calvo, J. R., Karasek, M., et al. (2005). Human lymphocyte-synthesized melatonin is involved in the regulation of the interleukin-2/Interleukin-2 receptor system. J. Clin. Endocrinol. Metab. 90, 992-1000. doi: 10.1210/jc.2004-1429

Clarke, G., Grenham, S., Scully, P., Fitzgerald, P., Moloney, R. D., Shanahan, F., et al. (2013). The microbiome-gut-brain axis during early life regulates the hippocampal serotonergic system in a sex-dependent manner. Mol. Psychiatry 18, 666-673. doi: 10.1038/mp.2012.77

Contreras, F., Prado, C., González, H., Franz, D., Osorio-Barrios, F., Osorio, F., et al. (2016). Dopamine receptor D3 signaling on CD4 $+\mathrm{T}$ cells favors Th1- and Th17-mediated immunity. J. Immunol. 196, 4143-4149. doi: 10.4049/ jimmunol.1502420

Cousin, C., Aubatin, A., Le Gouvello, S., Apetoh, L., Castellano, F., and MolinierFrenkel, V. (2015). The immunosuppressive enzyme IL4I1 promotes FoxP3 + regulatory T lymphocyte differentiation: immunomodulation. Eur. J. Immunol. 45, 1772-1782. doi: 10.1002/eji.201445000

de Araújo, E. F., Feriotti, C., Galdino, N. A., de, L., Preite, N. W., Calich, V. L. G., et al. (2017). The IDO-AhR axis controls Th17/Treg immunity in a pulmonary model of fungal infection. Front. Immunol. 8:880. doi: 10.3389/fimmu.2017. 00880

Derman, B. A., Streck, M., Wynne, J., Christ, T. N., Curran, E., Stock, W., et al. (2020). Efficacy and toxicity of reduced vs. standard dose pegylated asparaginase in adults with Philadelphia chromosome-negative acute lymphoblastic leukemia. Leuk. Lymphoma 61, 614-622. doi: 10.1080/10428194. 2019.1680839

Douguet, L., Bod, L., Labarthe, L., Lengagne, R., Kato, M., Couillin, I., et al. (2018). Inflammation drives nitric oxide synthase 2 expression by $\gamma \delta \mathrm{T}$ cells and affects the balance between melanoma and vitiligo associated melanoma. Oncoimmunology 7:e1484979. doi: 10.1080/2162402x.2018.1484979

Douguet, L., Bod, L., Lengagne, R., Labarthe, L., Kato, M., Avril, M.-F., et al. (2016a). Nitric oxide synthase 2 is involved in the pro-tumorigenic potential of $\gamma \delta 17 \mathrm{~T}$ cells in melanoma. Oncoimmunology 5:e1208878. doi: 10.1080/ 2162402x.2016.1208878

Douguet, L., Cherfils-Vicini, J., Bod, L., Lengagne, R., Gilson, E., and PrévostBlondel, A. (2016b). Nitric oxide synthase 2 improves proliferation and glycolysis of peripheral $\gamma \delta$ T cells. PLoS One 11:e0165639. doi: 10.1371/journal. pone. 0165639

Eleftheriadis, T., Pissas, G., Antoniadi, G., Tsogka, K., Sounidaki, M., Liakopoulos, V., et al. (2016). Indoleamine 2,3-dioxygenase downregulates T-cell receptor complex $\zeta$-chain and $\mathrm{c}-\mathrm{Myc}$, and reduces proliferation, lactate dehydrogenase levels and mitochondrial glutaminase in human T-cells. Mol. Med. Rep. 13, 925-932. doi: 10.3892/mmr.2015.4595

Farez, M. F., Calandri, I. L., Correale, J., and Quintana, F. J. (2016). Antiinflammatory effects of melatonin in multiple sclerosis. Bioessays 38, 10161026. doi: 10.1002/bies.201600018

Farez, M. F., Mascanfroni, I. D., Méndez-Huergo, S. P., Yeste, A., Murugaiyan, G., Garo, L. P., et al. (2015). Melatonin contributes to the seasonality of multiple sclerosis relapses. Cell 162, 1338-1352. doi: 10.1016/j.cell.2015.08.025

Ferlito, M., Irani, K., Faraday, N., and Lowenstein, C. J. (2006). Nitric oxide inhibits exocytosis of cytolytic granules from lymphokine-activated killer cells. Proc. Natl. Acad. Sci. U.S.A. 103, 11689-11694. doi: 10.1073/pnas.0600275103

Fletcher, M., Ramirez, M. E., Sierra, R. A., Raber, P., Thevenot, P., Al-Khami, A. A., et al. (2015). 1-Arginine depletion blunts antitumor T-cell responses by inducing myeloid-derived suppressor cells. Cancer Res. 75, 275-283. doi: 10.1158/0008-5472.can-14-1491

Fuchs, B. C., and Bode, B. P. (2005). Amino acid transporters ASCT2 and LAT1 in cancer: Partners in crime? Semin. Cancer Biol. 15, 254-266. doi: 10.1016/j. semcancer.2005.04.005

Gao, J., Xu, K., Liu, H., Liu, G., Bai, M., Peng, C., et al. (2018). Impact of the gut microbiota on intestinal immunity mediated by tryptophan metabolism. Front. Cell. Infect. Microbiol. 8:13. doi: 10.3389/fcimb.2018.00013

García-Ortiz, A., Martín-Cofreces, N. B., Ibiza, S., Ortega, Á., Izquierdo-Álvarez, A., Trullo, A., et al. (2017). eNOS S-nitrosylates $\beta$-actin on Cys374 and regulates PKC- $\theta$ at the immune synapse by impairing actin binding to profilin-1. PLoS Biol. 15:e2000653. doi: 10.1371/journal.pbio.2000653

García-Ortiz, A., and Serrador, J. M. (2018). Nitric oxide signaling in T cellmediated immunity. Trends Mol. Med. 24, 412-427. doi: 10.1016/j.molmed. 2018.02.002

Geiger, R., Rieckmann, J. C., Wolf, T., Basso, C., Feng, Y., Fuhrer, T., et al. (2016). L-arginine modulates $\mathrm{T}$ cell metabolism and enhances survival and anti-tumor activity. Cell 167, 829-842.e13.

Genius, J., Schellenberg, A., Tchana-Duope, L., Hartmann, N., Giegling, I., Hartmann, A., et al. (2015). Enhanced calcium responses to serotonin receptor stimulation in T-lymphocytes from schizophrenic patients - A pilot study. Neurosci. Lett. 589, 159-162. doi: 10.1016/j.neulet.2014.12.058

Ghosh, M. C., Mondal, A. C., Basu, S., Banerjee, S., Majumder, J., Bhattacharya, D., et al. (2003). Dopamine inhibits cytokine release and expression of tyrosine 
kinases, Lck and Fyn in activated T cells. Int. Immunopharmacol. 3, 1019-1026. doi: 10.1016/s1567-5769(03)00100-0

Gringhuis, S. I., Papendrecht-van der Voort, E. A. M., Leow, A., Levarht, E. W. N., Breedveld, F. C., and Verweij, C. L. (2002). Effect of redox balance alterations on cellular localization of LAT and downstream T-cell receptor signaling pathways. Mol. Cell. Biol. 22, 400-411. doi: 10.1128/mcb.22.2.400-411.2002

Hayashi, K., Jutabha, P., Endou, H., Sagara, H., and Anzai, N. (2013). LAT1 Is a critical transporter of essential amino acids for immune reactions in activated human T cells. J. Immunol. 191, 4080-4085. doi: 10.4049/jimmunol.1300923

Hodo, T. W., de Aquino, M. T. P., Shimamoto, A., and Shanker, A. (2020). Critical Neurotransmitters in the neuroimmune network. Front. Immunol. 11:1869. doi: $10.3389 /$ fimmu. 2020.01869

Huang, H., Long, L., Zhou, P., Chapman, N. M., and Chi, H. (2020). mTOR signaling at the crossroads of environmental signals and T-cell fate decisions. Immunol. Rev. 295, 15-38. doi: 10.1111/imr.12845

Iacono, A., Pompa, A., De Marchis, F., Panfili, E., Greco, F. A., Coletti, A., et al. (2020). Class IA PI3Ks regulate subcellular and functional dynamics of IDO1. EMBO Rep. 7:e49756. doi: 10.15252/embr.201949756

Ibiza, S., Víctor, V. M., Boscá, I., Ortega, A., Urzainqui, A., O’Connor, J. E., et al. (2006). Endothelial nitric oxide synthase regulates $\mathrm{T}$ cell receptor signaling at the immunological synapse. Immunity 24, 753-765. doi: 10.1016/j.immuni. 2006.04.006

Iken, K., Liu, K., Liu, H., Bizargity, P., Wang, L., Hancock, W. W., et al. (2012). Indoleamine 2,3-dioxygenase and metabolites protect murine lung allografts and impair the calcium mobilization of T cells. Am. J. Respir. Cell Mol. Biol. 47, 405-416. doi: 10.1165/rcmb.2011-0438oc

Kim, K., Jeong, J. H., Lim, D., Hong, Y., Lim, H.-J., Kim, G.-J., et al. (2015). LAsparaginase delivered by Salmonella typhimurium suppresses solid tumors. Mol. Ther. Oncolytics 2:15007. doi: 10.1038/mto.2015.7

Kustrimovic, N., Rasini, E., Legnaro, M., Marino, F., and Cosentino, M. (2014). Expression of dopaminergic receptors on human CD4+ T lymphocytes: flow cytometric analysis of naive and memory subsets and relevance for the neuroimmunology of neurodegenerative disease. J. Neuroimmune Pharmacol. 9, 302-312. doi: 10.1007/s11481-014-9541-5

Lamas, B., Hernandez-Galan, L., Galipeau, H. J., Constante, M., Clarizio, A., Jury, J., et al. (2020). Aryl hydrocarbon receptor ligand production by the gut microbiota is decreased in celiac disease leading to intestinal inflammation. Sci. Transl. Med. 12:eaba0624. doi: 10.1126/scitranslmed.aba0624

León-Ponte, M., Ahern, G. P., and O'Connell, P. J. (2007). Serotonin provides an accessory signal to enhance T-cell activation by signaling through the 5-HT7 receptor. Blood 109, 3139-3146. doi: 10.1182/blood-2006-10-052787

Levring, T. B., Hansen, A. K., Nielsen, B. L., Kongsbak, M., von Essen, M. R., Woetmann, A., et al. (2012). Activated human CD4+ T cells express transporters for both cysteine and cystine. Sci. Rep. 2:266.

Levring, T. B., Kongsbak, M., Rode, A. K. O., Woetmann, A., Ødum, N., Bonefeld, C. M., et al. (2015). Human CD4+ T cells require exogenous cystine for glutathione and DNA synthesis. Oncotarget 6, 21853-21864. doi: 10.18632/ oncotarget.5213

Li, R., Li, H., Sun, Q., Liu, L., Zhang, C., and Ren, X. (2017). Indoleamine 2,3dioxygenase regulates T cell activity through Vav1/Rac pathway. Mol. Immunol. 81, 102-107. doi: 10.1016/j.molimm.2016.11.018

Li, R., Wei, F., Yu, J., Li, H., Ren, X., and Ren, X. (2009). IDO inhibits T-cell function through suppressing Vav1 expression and activation. Cancer Biol. Ther. 8, 1402-1408. doi: 10.4161/cbt.8.14.8882

Líndez, A.-A. M., Dunand-Sauthier, I., Conti, M., Gobet, F., Núñez, N., Hannich, J. T., et al. (2019). Mitochondrial arginase-2 is a cell-autonomous regulator of CD8+ T cell function and antitumor efficacy. JCI Insight 4:e132975.

Lowe, M. M., Boothby, I., Clancy, S., Ahn, R. S., Liao, W., Nguyen, D. N., et al. (2019). Regulatory T cells use arginase 2 to enhance their metabolic fitness in tissues. JCI Insight 4:e129756.

Ma, Z., Zhen, Y., Hu, C., and Yi, H. (2020). Myeloid-derived suppressor cellderived arginase-1 oppositely modulates IL-17A and IL-17F through the ESR/STAT3 pathway during colitis in mice. Front. Immunol. 11:687. doi: 10. 3389/fimmu.2020.00687

Magrini, E., Szabò, I., Doni, A., Cibella, J., and Viola, A. (2011). Serotonin-mediated tuning of human helper T cell responsiveness to the chemokine CXCL12. PLoS One 6:e22482. doi: 10.1371/journal.pone.0022482
Mak, T. W., Grusdat, M., Duncan, G. S., Dostert, C., Nonnenmacher, Y., Cox, M., et al. (2017). Glutathione primes $\mathrm{T}$ cell metabolism for inflammation. Immunity 46, 675-689. doi: 10.1016/j.immuni.2017.03.019

Marquet, J., Lasoudris, F., Cousin, C., Puiffe, M.-L., Martin-Garcia, N., Baud, V., et al. (2010). Dichotomy between factors inducing the immunosuppressive enzyme IL-4-induced gene 1 (IL4I1) in B lymphocytes and mononuclear phagocytes. Eur. J. Immunol. 40, 2557-2568. doi: 10.1002/eji.201040428

Martínez, Y., Li, X., Liu, G., Bin, P., Yan, W., Más, D., et al. (2017). The role of methionine on metabolism, oxidative stress, and diseases. Amino Acids 49, 2091-2098.

Mason, J. M., Naidu, M. D., Barcia, M., Porti, D., Chavan, S. S., and Chu, C. C. (2004). IL-4-induced gene-1 is a leukocyte l-amino acid oxidase with an unusual acidic $\mathrm{pH}$ preference and lysosomal localization. J. Immunol. 173, 4561-4567. doi: 10.4049/jimmunol.173.7.4561

Meng, T.-C., Fukada, T., and Tonks, N. K. (2002). Reversible oxidation and inactivation of protein tyrosine phosphatases in vivo. Mol. Cell 9, 387-399. doi: 10.1016/s1097-2765(02)00445-8

Metz, R., Rust, S., DuHadaway, J. B., Mautino, M. R., Munn, D. H., Vahanian, N. N., et al. (2012). IDO inhibits a tryptophan sufficiency signal that stimulates mTOR: a novel IDO effector pathway targeted by D-1-methyl-tryptophan. Oncoimmunology 1, 1460-1468. doi: 10.4161/onci.21716

Mezrich, J. D., Fechner, J. H., Zhang, X., Johnson, B. P., Burlingham, W. J., and Bradfield, C. A. (2010). An interaction between Kynurenine and the Aryl hydrocarbon receptor can generate regulatory T cells. J. Immunol. 185, 3190-3198. doi: 10.4049/jimmunol.0903670

Molinier-Frenkel, V., Mestivier, D., and Castellano, F. (2016). Alterations of the immunosuppressive IL4I1 enzyme activity induced by naturally occurring SNP/mutations. Genes Immun. 17, 148-152. doi: 10.1038/gene.2015.55

Molinier-Frenkel, V., Prévost-Blondel, A., and Castellano, F. (2019). The IL4I1 enzyme: a new player in the immunosuppressive tumor microenvironment. Cells 8:757. doi: $10.3390 /$ cells 8070757

Mondanelli, G., Bianchi, R., Pallotta, M. T., Orabona, C., Albini, E., Iacono, A., et al. (2017). A relay pathway between arginine and tryptophan metabolism confers immunosuppressive properties on dendritic cells. Immunity 46, 233-244. doi: 10.1016/j.immuni.2017.01.005

Munder, M., Eichmann, K., Morán, J. M., Centeno, F., Soler, G., and Modolell, M. (1999). Th1/Th2-regulated expression of arginase isoforms in murine macrophages and dendritic cells. J. Immunol. 163, 3771-3777.

Nakaya, M., Xiao, Y., Zhou, X., Chang, J.-H., Chang, M., Cheng, X., et al. (2014). Inflammatory $T$ cell responses rely on amino acid transporter ASCT2 Facilitation of glutamine uptake and mTORC1 kinase activation. Immunity 40, 692-705. doi: 10.1016/j.immuni.2014.04.007

Nicklin, P., Bergman, P., Zhang, B., Triantafellow, E., Wang, H., Nyfeler, B., et al. (2009). Bidirectional transport of amino acids regulates mTOR and autophagy. Cell 136, 521-534. doi: 10.1016/j.cell.2008.11.044

Niedbala, W., Alves-Filho, J. C., Fukada, S. Y., Vieira, S. M., Mitani, A., Sonego, F., et al. (2011). Regulation of type 17 helper T-cell function by nitric oxide during inflammation. Proc. Natl. Acad. Sci. U.S.A. 108, 9220-9225. doi: 10.1073/pnas. 1100667108

Niedbala, W., Cai, B., Liu, H., Pitman, N., Chang, L., and Liew, F. Y. (2007). Nitric oxide induces CD4+CD25+ Foxp3 regulatory T cells from CD4+CD25 T cells via p53, IL-2, and OX40. Proc. Natl. Acad. Sci. U.S.A. 104, 15478-15483. doi: 10.1073/pnas.0703725104

Ninomiya, S., Narala, N., Huye, L., Yagyu, S., Savoldo, B., Dotti, G., et al. (2015). Tumor indoleamine 2,3-dioxygenase (IDO) inhibits CD19-CAR T cells and is downregulated by lymphodepleting drugs. Blood 125, 3905-3916. doi: 10.1182/ blood-2015-01-621474

Obermajer, N., Wong, J. L., Edwards, R. P., Chen, K., Scott, M., Khader, S., et al. (2013). Induction and stability of human Th17 cells require endogenous NOS2 and cGMP-dependent NO signaling. J. Exp. Med. 210, 1433-1445. doi: 10.1084/ jem.20121277

O’Mahony, S. M., Clarke, G., Borre, Y. E., Dinan, T. G., and Cryan, J. F. (2015). Serotonin, tryptophan metabolism and the brain-gut-microbiome axis. Behav. Brain Res. 277, 32-48. doi: 10.1016/j.bbr.2014.07.027

Onyema, O. O., Guo, Y., Mahgoub, B., Wang, Q., Manafi, A., Mei, Z., et al. (2019). Eosinophils downregulate lung alloimmunity by decreasing TCR signal transduction. JCI Insight 4:e128241. 
Opitz, C. A., Litzenburger, U. M., Sahm, F., Ott, M., Tritschler, I., Trump, S., et al. (2011). An endogenous tumour-promoting ligand of the human aryl hydrocarbon receptor. Nature 478, 197-203. doi: 10.1038/nature10491

Pallotta, M. T., Orabona, C., Volpi, C., Vacca, C., Belladonna, M. L., Bianchi, R., et al. (2011). Indoleamine 2,3-dioxygenase is a signaling protein in long-term tolerance by dendritic cells. Nat. Immunol. 12, 870-878. doi: 10.1038/ni.2077

Papa, I., Saliba, D., Ponzoni, M., Bustamante, S., Canete, P. F., Gonzalez-Figueroa, P., et al. (2017). TFH-derived dopamine accelerates productive synapses in germinal centres. Nature 547, 318-323. doi: 10.1038/nature23013

Pedrosa, A. M., da, C., Weinlich, R., Mognol, G. P., Robbs, B. K., Viola, J. P., et al. (2010). Melatonin protects CD4 $+\mathrm{T}$ cells from activation-induced cell death by blocking NFAT-Mediated CD95 ligand upregulation. J. Immunol. 184, 3487-3494. doi: 10.4049/jimmunol.0902961

Puiffe, M.-L., Dupont, A., Sako, N., Gatineau, J., Cohen, J. L., Lebon, A., et al. (2020). IL4I1 accelerates the expansion of effector CD8+ T cells at the expense of memory precursors by increasing the threshold of $\mathrm{T}$ cell activation. Front. Immunol. 11:3145. doi: 10.3389/fimmu.2020.600012

Ren, W., Liu, G., Yin, J., Tan, B., Wu, G., Bazer, F. W., et al. (2017). Amino-acid transporters in T-cell activation and differentiation. Cell Death Dis. 8:e2655. doi: 10.1038/cddis.2016.222

Rodriguez, P. C., Ernstoff, M. S., Hernandez, C., Atkins, M., Zabaleta, J., Sierra, R., et al. (2009). Arginase I-producing myeloid-derived suppressor cells in renal cell carcinoma are a subpopulation of activated granulocytes. Cancer Res. 69, 1553-1560. doi: 10.1158/0008-5472.can-08-1921

Rodriguez, P. C., Hernandez, C. P., Morrow, K., Sierra, R., Zabaleta, J., Wyczechowska, D. D., et al. (2010). 1-Arginine deprivation regulates cyclin D3 mRNA stability in human T cells by controlling HuR expression. J. Immunol. 185, 5198-5204. doi: 10.4049/jimmunol.1001224

Rodriguez, P. C., Ochoa, A. C., and Al-Khami, A. A. (2017). Arginine metabolism in myeloid cells shapes innate and adaptive immunity. Front. Immunol. 8:93. doi: 10.3389/fimmu.2017.00093/full

Rodriguez, P. C., Quiceno, D. G., and Ochoa, A. C. (2007). 1-arginine availability regulates T-lymphocyte cell-cycle progression. Blood 109, 1568-1573. doi: 10 . 1182/blood-2006-06-031856

Rodriguez, P. C., Zea, A. H., DeSalvo, J., Culotta, K. S., Zabaleta, J., Quiceno, D. G., et al. (2003). 1-Arginine consumption by macrophages modulates the expression of $\mathrm{CD} 3 \zeta$ Chain in $\mathrm{T}$ lymphocytes. J. Immunol. 171, 1232-1239. doi: 10.4049/jimmunol.171.3.1232

Ron-Harel, N., Ghergurovich, J. M., Notarangelo, G., LaFleur, M. W., Tsubosaka, Y., Sharpe, A. H., et al. (2019). T cell activation depends on extracellular alanine. Cell Rep. 28, 3011-3021.e4.

Sacramento, P. M., Monteiro, C., Dias, A. S. O., Kasahara, T. M., Ferreira, T. B., Hygino, J., et al. (2018). Serotonin decreases the production of Th1/Th17 cytokines and elevates the frequency of regulatory CD4+ T-cell subsets in multiple sclerosis patients. Eur. J. Immunol. 48, 1376-1388. doi: 10.1002/eji. 201847525

Sadik, A., Somarribas Patterson, L. F., Öztürk, S., Mohapatra, S. R., Panitz, V., Secker, P. F., et al. (2020). IL4I1 is a metabolic immune checkpoint that activates the AHR and promotes tumor progression. Cell 182, 1252-1270.e34.

Saini, A. S., Shenoy, G. N., Rath, S., Bal, V., and George, A. (2014). Inducible nitric oxide synthase is a major intermediate in signaling pathways for the survival of plasma cells. Nat. Immunol. 15, 275-282. doi: 10.1038/ni.2806

Sarkar, C., Das, S., Chakroborty, D., Chowdhury, U. R., Basu, B., Dasgupta, P. S., et al. (2006). Cutting edge: stimulation of dopamine D 4 receptors induce $\mathrm{T}$ cell quiescence by up-regulating Krüppel-Like Factor-2 expression through inhibition of ERK1/ERK2 phosphorylation. J. Immunol. 177, 7525-7529. doi: 10.4049/jimmunol.177.11.7525

Sinclair, L. V., Howden, A. J., Brenes, A., Spinelli, L., Hukelmann, J. L., Macintyre, A. N., et al. (2019). Antigen receptor control of methionine metabolism in T cells. eLife 8:e44210.

Sinclair, L. V., Rolf, J., Emslie, E., Shi, Y.-B., Taylor, P. M., and Cantrell, D. A. (2013). Control of amino-acid transport by antigen receptors coordinates the metabolic reprogramming essential for T cell differentiation. Nat. Immunol. 14, 500-508. doi: $10.1038 /$ ni.2556

Song, P., Wang, Z., Zhang, X., Fan, J., Li, Y., Chen, Q., et al. (2017). The role of autophagy in asparaginase-induced immune suppression of macrophages. Cell Death Dis. 8:e2721. doi: 10.1038/cddis.2017.144
Srivastava, M. K., Sinha, P., Clements, V. K., Rodriguez, P., and OstrandRosenberg, S. (2010). Myeloid-derived suppressor cells inhibit T-cell activation by depleting cystine and cysteine. Cancer Res. 70, 68-77. doi: 10.1158/00085472.can-09-2587

Steplewski, Z., and Vogel, W. H. (1985). Changes in brain serotonin levels affect leukocytes, lymphocytes, T-cell subpopulations and natural killer cell activity in rats. Neurosci. Lett. 62, 277-282. doi: 10.1016/0304-3940(85)90368-4

Strell, C., Sievers, A., Bastian, P., Lang, K., Niggemann, B., Zänker, K. S., et al. (2009). Divergent effects of norepinephrine, dopamine and substance P on the activation, differentiation and effector functions of human cytotoxic $\mathrm{T}$ lymphocytes. BMC Immunol. 10:62. doi: 10.1186/1471-2172-10-62

Taheri, F., Ochoa, J. B., Faghiri, Z., Culotta, K., Park, H.-J., Lan, M. S., et al. (2001). Arginine regulates the expression of the T-cell receptor $\zeta$ Chain (CD3 $\zeta)$ in Jurkat cells. Clin. Cancer Res. 7(3 Suppl.), 958s-965s.

Tarocco, A., Caroccia, N., Morciano, G., Wieckowski, M. R., Ancora, G., Garani, G., et al. (2019). Melatonin as a master regulator of cell death and inflammation: molecular mechanisms and clinical implications for newborn care. Cell Death Dis. 10:317.

Torres, A., Luke, J. D., Kullas, A. L., Kapilashrami, K., Botbol, Y., Koller, A., et al. (2016). Asparagine deprivation mediated by Salmonella asparaginase causes suppression of activation-induced $\mathrm{T}$ cell metabolic reprogramming. J. Leukoc. Biol. 99, 387-398. doi: 10.1189/jlb.4a0615-252r

Uchino, H., Kanai, Y., Kim, D. K., Wempe, M. F., Chairoungdua, A., Morimoto, E., et al. (2002). Transport of amino acid-related compounds mediated by L-type amino acid transporter 1 (LAT1): insights into the mechanisms of substrate recognition. Mol. Pharmacol. 61, 729-737. doi: 10.1124/mol.61.4.729

Victora, G. D., Schwickert, T. A., Fooksman, D. R., Kamphorst, A. O., MeyerHermann, M., Dustin, M. L., et al. (2010). Germinal center dynamics revealed by multiphoton microscopy with a photoactivatable fluorescent reporter. Cell 143, 592-605. doi: 10.1016/j.cell.2010.10.032

Wang, Z., Yip, L. Y., Lee, J. H. J., Wu, Z., Chew, H. Y., Chong, P. K. W., et al. (2019). Methionine is a metabolic dependency of tumor-initiating cells. Nat. Med. 25, 825-837.

Werner, A., Amann, E., Schnitzius, V., Habermeier, A., Luckner-Minden, C., Leuchtner, N., et al. (2016). Induced arginine transport via cationic amino acid transporter-1 is necessary for human T-cell proliferation: cellular immune response. Eur. J. Immunol. 46, 92-103. doi: 10.1002/eji.201546047

Werner, A., Koschke, M., Leuchtner, N., Luckner-Minden, C., Habermeier, A., Rupp, J., et al. (2017). Reconstitution of T cell proliferation under arginine limitation: activated human $\mathrm{T}$ cells take up citrulline via L-type amino acid transporter 1 and use it to regenerate Arginine after induction of Argininosuccinate synthase expression. Front. Immunol. 8:864. doi: 10.3389/ fimmu.2017.00864

Wikoff, W. R., Anfora, A. T., Liu, J., Schultz, P. G., Lesley, S. A., Peters, E. C., et al. (2009). Metabolomics analysis reveals large effects of gut microflora on mammalian blood metabolites. Proc. Natl. Acad. Sci. U.S.A. 106, 3698-3703. doi: $10.1073 /$ pnas.0812874106

Wojciech, L., Tan, K. S. W., and Gascoigne, N. R. J. (2020). Taming the sentinels: microbiome-derived metabolites and polarization of T cells. Int. J. Mol. Sci. 21:7740. doi: 10.3390/ijms21207740

Wu, H., Zhen, Y., Ma, Z., Li, H., Yu, J., Xu, Z.-G., et al. (2016). Arginase-1dependent promotion of $\mathrm{T} H 17$ differentiation and disease progression by MDSCs in systemic lupus erythematosus. Sci. Transl. Med. 8:331ra40. doi: 10.1126/scitranslmed.aae0482

Xia, Y., and Zweier, J. L. (1997). Superoxide and peroxynitrite generation from inducible nitric oxide synthase in macrophages. Proc. Natl. Acad. Sci. U.S.A. 94, 6954-6958. doi: 10.1073/pnas.94.13.6954

Xu, Y., Li, Z., Yin, Y., Lan, H., Wang, J., Zhao, J., et al. (2015). Ghrelin inhibits the differentiation of T helper 17 Cells through mTOR/STAT3 signaling pathway. PLoS One 10:e0117081. doi: 10.1371/journal.pone.0117081

Yang, J., Zhang, R., Lu, G., Shen, Y., Peng, L., Zhu, C., et al. (2013). T cell-derived inducible nitric oxide synthase switches off TH17 cell differentiation. J. Exp. Med. 210, 1447-1462. doi: 10.1084/jem.20122494

Yue, Y., Huang, W., Liang, J., Guo, J., Ji, J., Yao, Y., et al. (2015). IL4I1 is a novel regulator of M2 macrophage polarization that can inhibit $\mathrm{T}$ cell activation via L-tryptophan and arginine depletion and IL-10 production. PLoS One 10:e0142979. doi: 10.1371/journal.pone.0142979 
Zanin-Zhorov, A., Ding, Y., Kumari, S., Attur, M., Hippen, K. L., Brown, M., et al. (2010). Protein Kinase C- mediates negative feedback on regulatory $\mathrm{T}$ cell function. Science 328, 372-376. doi: 10.1126/science.11 86068

Zhang, X., Gan, M., Li, J., Li, H., Su, M., Tan, D., et al. (2020). Endogenous indole pyruvate pathway for tryptophan metabolism mediated by IL4I1. J. Agric. Food Chem. 68, 10678-10684. doi: 10.1021/acs.jafc.0c03735

Zheng, Y., Delgoffe, G. M., Meyer, C. F., Chan, W., and Powell, J. D. (2009). Anergic T cells are metabolically anergic. J. Immunol. 183, 6095-6101. doi: 10.4049/jimmunol.0803510
Conflict of Interest: The authors declare that the research was conducted in the absence of any commercial or financial relationships that could be construed as a potential conflict of interest.

Copyright (C) 2020 Castellano and Molinier-Frenkel. This is an open-access article distributed under the terms of the Creative Commons Attribution License (CC BY). The use, distribution or reproduction in other forums is permitted, provided the original author(s) and the copyright owner(s) are credited and that the original publication in this journal is cited, in accordance with accepted academic practice. No use, distribution or reproduction is permitted which does not comply with these terms. 